Document downloaded from:

http://hdl.handle.net/10251/145991

This paper must be cited as:

Reibner, AM.; Al Hamimi, S.; Quiles Chuliá, MD.; Schmidt, C.; Struck, S.; Hernando Hernando, MI.; Turner, C.... (08-2). Composition and physicochemical properties of dried berry pomace. Journal of the Science of Food and Agriculture. 99(3):1284-1293. https://doi.org/10.1002/jsfa.9302

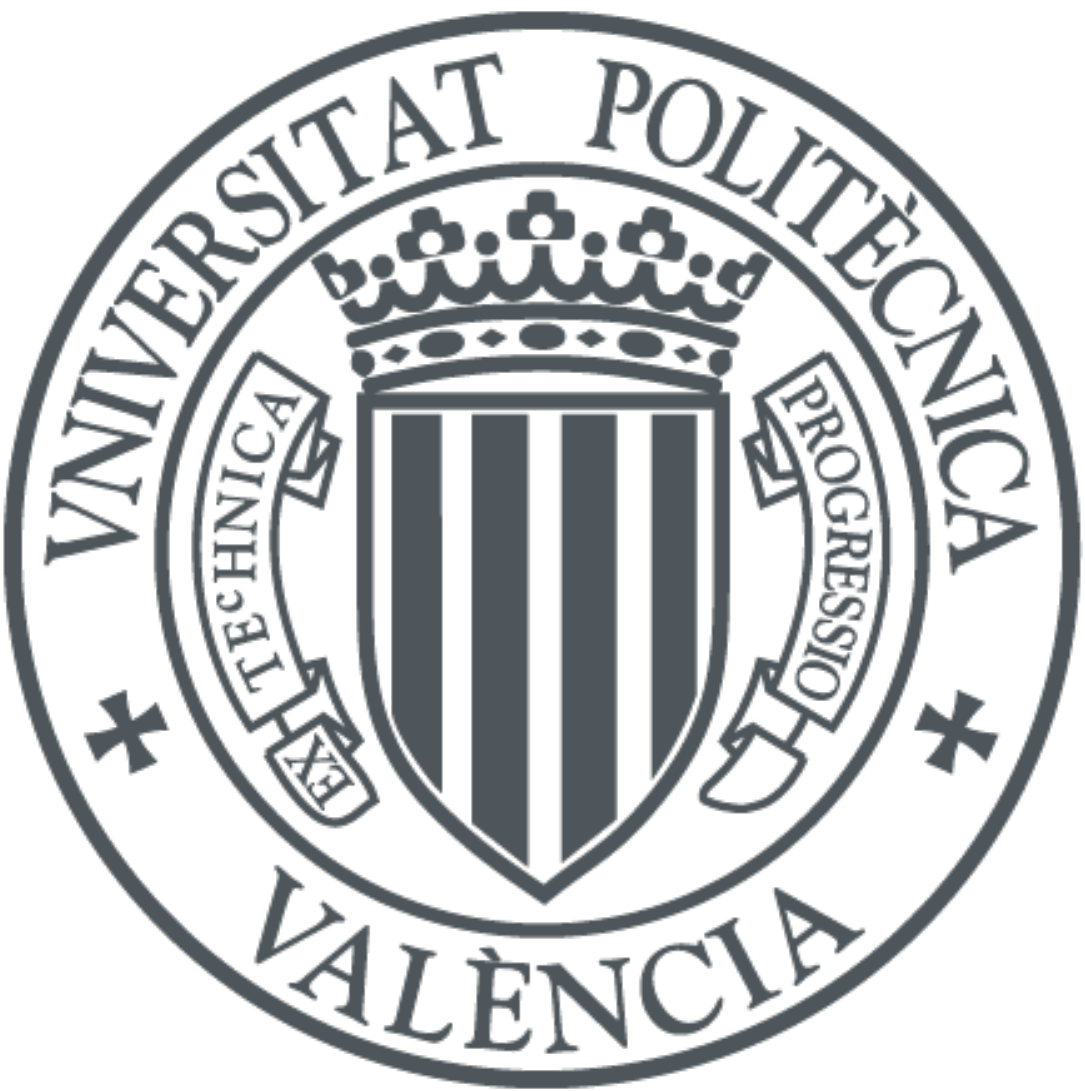

The final publication is available at

https://doi.org/10.1002/jsfa.9302

Copyright John Wiley \& Sons

Additional Information 


\title{
Composition and physicochemical properties of dried berry
}

\author{
pomace
}

\author{
Anne-Marie Reißner ${ }^{1}$, Said Al-Hamimi ${ }^{3}$, Amparo Quiles ${ }^{2}$, Carolin Schmidt ${ }^{1}$, Susanne \\ Struck $^{1}$, Isabel Hernando ${ }^{2}$, Charlotta Turner ${ }^{3}$, Harald Rohm ${ }^{1}$ \\ ${ }^{1}$ Chair of Food Engineering, Technische Universität Dresden, 01062 Dresden, \\ Germany \\ ${ }^{2}$ Research Group of Food Microstructure and Chemistry, Universitat Politècnica de \\ Valencia, 46022, Valencia, Spain \\ ${ }^{3}$ Department of Chemistry, Centre for Analysis \& Synthesis, Lund University, 22362 \\ Lund, Sweden
}

Running title: Composition and technofunctional properties of berry pomace Keywords: berry pomace, sustainability, dietary fibre, technofunctional properties, polyphenols, vapour sorption

Correspondence to:

Anne-Marie Reißner

Chair of Food Engineering

Technische Universität Dresden

01062 Dresden

This article has been accepted for publication and undergone full peer review but has not been through the copyediting, typesetting, pagination and proofreading process which may lead to differences between this version and the Version of Record. Please cite this article as doi: $10.1002 /$ jsfa. 9302 


\section{Germany}

E-Mail: anne-marie.reissner@tu-dresden.de 


\section{Abstract}

BACKGROUND: Berry pomace is a valuable but still little used by-product from juice manufacture. When processed to a stable fruit powder, the composition differs from that of the whole fruit. To facilitate the application in foods, detailed knowledge of its composition and physicochemical properties is essential.

RESULTS: Blackcurrant, redcurrant, chokeberry, rowanberry and gooseberry were selected for analysis. All pomace powders had a high fibre content ( $>550 \mathrm{~g} \mathrm{~kg}^{-1}$ ) and a fat content of up to $200 \mathrm{~g} \mathrm{~kg}^{-1}$. Despite identical milling conditions, the particle sizes of the pomace powders varied. This can be traced back to seed content and brittleness, becoming also apparent in surface characteristics. Blackcurrant pomace powder differed from other varieties by its low water binding capacity $\left(3.2 \mathrm{~g} \mathrm{~g}^{-1}\right)$ and a moderate moisture uptake, whereas chokeberry pomace powder showed the highest polyphenol content and rowanberry pomace powder was rich in flavonols.

CONCLUSION: The results obtained in this study give a comprehensive overview on the properties of berry pomace powder and allow drawing conclusions on their applicability for being used in complex food systems.

\section{INTRODUCTION}

The recommended daily dietary fibre intake of human adults is $25 \mathrm{~g}$, and $70-80 \%$ of that amount should be insoluble. ${ }^{1,2}$ One prominent possibility to increase fibre content of the diet for enhancing the still-too-low intake is to supplement foods with fibre from cereal origin. ${ }^{3}$ Alternatively, increased fibre intake may be achieved by adding fruit processing by-products. A further use of, for instance, pomace adds 
value to a material that is usually treated as waste, and therefore contributes to an improved sustainability of the agri-food processing chain.

The composition of apple and citrus pomace powders has been widely studied, and respective fibre products are commercially available. ${ }^{2,4}$ These pomaces are especially interesting because of their high pectin content, but recent research also examined applications of apple and citrus fibre that are based on their chemical and technofunctional properties. ${ }^{5,6}$ Apart from dietary fibre, berry pressing residues contain high amounts of bioactive compounds which may trigger health promoting effects once incorporated in the human $\mathrm{diet}^{7}$ and therefore make them an interesting study subject.

Water soluble antioxidant components located in the cell vacuole (for instance, chlorogenic acid) are released into the juice during pressing whereas compounds with low solubility (e.g., anthocyanins) that are associated with the cell wall remain in the pomace. ${ }^{8}$ It has been shown that the total dry matter (d.m.) related polyphenol content of chokeberry and blackcurrant press residues is $1.3-1.7$ times higher than that of the respective berries. ${ }^{9,10}$ Physiological functions of dietary fibre in human digestion derive from their physicochemical properties, including water and fat binding capacity, swelling ability, and rheological properties. ${ }^{11}$ In addition, quantification of the respective properties allows drawing conclusions on possible food applications. For instance, fibre with a high fat binding capacity might be best applied to stabilize fat in emulsion based products, whereas high water binding can be linked to decreasing syneresis in hydrogels, or altering food viscosity and texture. ${ }^{4,12}$

Although it has been mentioned that pomace from pooled lots of berries from different producers may contain a large number of different pesticides, ${ }^{13}$ the 
few studies available on the topic indicated that berries usually carry a low pesticide level, and that the pesticide level of pressing residues does not exceed that of fresh fruits. ${ }^{13,14,15}$ By taking these facts and the positive consumer image into account, by-products of berry juice production may serve as promising food ingredients with health promoting effects. ${ }^{7,16}$ Once processed into stable powder, a wide range of applications is possible. Prominent examples are baked or extruded cereal products where dried pomace may be used for partially replacing wheat, fat or sugar, ${ }^{17-19}$ or in meat or fish products for enhancing texture, and water and fat binding properties. $^{12,20}$

In industrial juice production berries are usually crushed or mashed, heated to $40-50{ }^{\circ} \mathrm{C}$ and treated with depectinising enzymes to disrupt the viscous gels formed during mashing so that extraction is facilitated. ${ }^{7,21}$ The remaining pomace is, because of its sugar content, highly susceptible to microbial spoilage ${ }^{22}$ so that immediate drying, accompanied by optimum milling, is necessary to control the fate of polyphenols and other heat-sensitive compounds. ${ }^{8}$

Fortifying foods with ingredients with high fibre content often (e.g. ${ }^{12,17-20}$ ) results in an unfortunate alteration of product characteristics which, to some extent, may be counteracted by formulation or process adaptation. ${ }^{23}$ Knowledge of technofunctional properties in combination with physical characteristics and chemical composition is required to evaluate the potential for the application of dried berry pomace. The aim of the present study was to investigate composition, microbiological state, polyphenol content and physical properties of processed berry pomace, and to show similarities and differences among five different berry varieties. The information on the characteristics of berry pomace powder is helpful to facilitate its further application in foods. 


\section{MATERIALS AND METHODS}

\section{Berry pomace as raw material and processing of pomace powder}

Berry pomace was collected from juice processors in the 2015 harvesting period on the day of pressing. Processed berry varieties were Ribes nigrum blackcurrant (BC, from Döhler GmbH, Neuenkirchen Hadeln, Germany), Aronia melanocarpa chokeberry (CB), $R$. rubrum redcurrant (RC) and $R$. uva-crispa gooseberry (GB) from Kelterei Walther GmbH, Arnsdorf, Germany, and Sorbus aucuparia rowanberry (RB, from Kelterei Kühne, Haselbachtal, Germany). The pomaces contained stems, seeds and skins and were stored at $-20^{\circ} \mathrm{C}$ in ziplock bags in $10-15 \mathrm{~kg}$ batches.

After thawing for $24 \mathrm{~h}$ at $8{ }^{\circ} \mathrm{C}$ berry pomace was dried in an ULE 400 convection oven (Memmert GmbH \& Co. KG, Schwabach, Germany) at $60^{\circ} \mathrm{C}$ for 24 $\mathrm{h}$, sufficient to reach a moisture content below $60 \mathrm{~g} \mathrm{~kg}^{-1}$. The dried material was subsequently milled in a ZM 100 ultra-centrifugal mill, equipped with a $0.5 \mathrm{~mm}$ sieve (Retsch $\mathrm{GmbH}$, Haan, Germany) at $14,000 \mathrm{rpm}$, and used for all subsequent analysis except for seed - and polyphenols content.

For polyphenol analysis, fresh pomace was freeze-dried at $-42{ }^{\circ} \mathrm{C}$ for $72 \mathrm{~h}$ in an Alpha 1-2 LDplus (Martin Christ Gefriertrocknungsanlagen $\mathrm{GmbH}$, Osterode, Germany) and milled after lyophilisation, again by using the ZM 100 mill operating at conditions described above.

\section{Microbiological analysis}

Five grams of fresh berry pomace or dried berry pomace powder were suspended in $45 \mathrm{~mL}$ sterile peptone water $\left(1.0 \mathrm{~g} \mathrm{~L}^{-1}\right.$ casein peptone, $8.5 \mathrm{~g} \mathrm{~L}^{-1}$ sodium chloride) and homogenized in a Stomacher 400 (Seward Ltd, Worthing, UK) for 5 min. The 
solution was decimally diluted and pour-plated with plate count agar (incubation: $30^{\circ} \mathrm{C}, 48 \mathrm{~h}$ ) for total mesophilic count and yeast extract glucose chloramphenicol agar (incubation: $25^{\circ} \mathrm{C}, 72 \mathrm{~h}$; both from Carl Roth $\mathrm{GmbH} \&$ Co. KG, Karlsruhe, Germany) for yeast and moulds.

\section{Proximate analysis}

Moisture content of fresh and dried berry pomace was determined by drying at 103 ${ }^{\circ} \mathrm{C}$ to constant mass. Fat content was analysed by acid hydrolysis and subsequent Soxhlet extraction with petroleum ether, crude protein by the Kjeldahl procedure (conversion factor 5.3), and ash content after incineration in a muffle furnace ( $4 \mathrm{~h}$, $550^{\circ} \mathrm{C}$ ). Soluble (SDF) and insoluble dietary fibre (IDF) were analysed using the total dietary fibre kit (Megazyme u.c., Bray, Ireland) based on AOAC 991.43. ${ }^{24}$ The remaining difference to $100 \%$ was considered as being non-DF carbohydrates. Total acidity was determined as tartaric acid equivalent after titration of an aqueous pomace powder suspension $\left(50 \mathrm{~g} \mathrm{~L}^{-1}\right.$ ) with $0.1 \mathrm{~mol} \mathrm{~L}^{-1}$ sodium hydroxide.

\section{Extraction and HPLC-DAD-MS analysis of phenolic compounds}

Pomace samples were extracted using a pressurized hot water extraction method. ${ }^{25}$ Briefly, $1 \mathrm{~g}$ of milled berry pomace was extracted with degassed Milli-Q water containing $50 \mathrm{~mL} \mathrm{~L}^{-1}$ ethanol and $10 \mathrm{~mL} \mathrm{~L}^{-1}$ formic acid in a $10.0 \mathrm{~mL}$ extraction cell using an ASE-350 system (DIONEX Softron GmbH, Germering, Germany). Extractions were performed at $99^{\circ} \mathrm{C}$ with 5 min preheating and 1 min static extraction. After that, the sample was flushed with fresh solvent ( $50 \%$ of the vessel volume). Extracts were diluted to a final volume of $25 \mathrm{~mL}$ with the extraction liquid 
(see above) and stored at $-20^{\circ} \mathrm{C}$. Prior to analysis, the extracts were centrifuged for 5 min to remove any undissolved particles.

HPLC-DAD analyses were performed on a Dionex UltiMate-3000 HPLC system equipped with an online degasser, a dual gradient solvent pump, a thermostatted autosampler, a column oven, and a Diode Array Detector (DAD). The system was controlled and data acquired using Chromeleon 6.80 software. Separations were performed by injecting $5 \mu \mathrm{L}$ of the extract on a porous-shell fused core Ascentis Express $\mathrm{C}_{18}$ column $(100 \mathrm{~mm} \times 3.0 \mathrm{~mm}, 2.7 \mu \mathrm{m}$; Supelco, Bellefonte, $\mathrm{PA})$. Column temperature and flow rate were set to $45^{\circ} \mathrm{C}$ and $350 \mu \mathrm{L} \mathrm{min}{ }^{-1}$, respectively. The mobile phase consisted of $(A)$ water and (B) methanol, both containing $10 \mathrm{~mL} \mathrm{~L}^{-1}$ formic acid. The gradient starting with $5 \%$ (B) was kept constant for three min and then linearly increased to $80 \%$ (B) during $30 \mathrm{~min}$. Chromatograms were recorded at $280 \mathrm{~nm}$ for total phenolics, at $350 \mathrm{~nm}$ for flavonoids and at $520 \mathrm{~nm}$ for anthocyanins. The mass spectrometer was scanning from 50 to $1100 \mathrm{~m} / \mathrm{z}$, the cone voltage was set to $35 \mathrm{~V}$ and the capillary voltage to 2.5 and $3.0 \mathrm{kV}$ for positive and negative ESI mode, respectively. The desolvation gas flow rate was $800 \mathrm{~L} \mathrm{~h}^{-1}$ at a temperature of $550{ }^{\circ} \mathrm{C}$ and the cone gas flow rate was $40 \mathrm{~L} \mathrm{~h}^{-1}$. The source temperature was $120^{\circ} \mathrm{C}$. $\mathrm{MS}^{\mathrm{E}}$ was performed with collision energy ramped from 15 to $50 \mathrm{eV}$. The system was controlled by and data acquired using MassLynx 4.1 (Waters MS Technologies, Sollentuna, Sweden).

\section{Determination of physical properties}

Particle size

Particle size distribution of milled berry pomace was determined with a HELOS/KRH2487 laser diffraction spectrometer (Sympatec GmbH, Clausthal-Zellerfeld, 
Germany). Before analysis at a dispersion pressure of $0.3 \mathrm{MPa}$ the powder was passed through a $2000 \mu \mathrm{m}$ sieve. Volume based median values $\mathrm{X}_{50}$ and $\mathrm{x}_{90}$, and specific surface area was calculated from the size distribution densities.

\section{Pomace seed content}

Dried pomace was ground for 3 min at maximum speed (level 10) in a berlinett CM5100 knife mill (VEB EMK, Berlin, Germany). It was verified in preliminary experiments using light microscopy that, under these conditions, only stems and skins were comminuted whereas seeds remained intact. Subsequently, the seeds were separated using an AS 200 vibratory sieve shaker (Retsch $\mathrm{GmbH}$, Haan, Germany), weighed, and expressed as fraction of whole dried pomace.

\section{Microstructure}

Pomace powder was vacuum coated with platinum and observed under a field emission scanning electron microscope (model Ultra 55 FESEM, Zeiss, Oberkochen, Germany). Each sample was analysed in duplicate.

A light microscope (Nikon Eclipse 80i, Nikon Co., Ltd., Tokyo, Japan) was used to study the structure of different pomaces according to Hernández-Carrión et al. ${ }^{26}$ The autofluorescence of the samples containing phenolic compounds was observed while using a mercury arc lamp with a TRITC filter $\left(\lambda_{\mathrm{ex}}=543 / 22 \mathrm{~nm}\right.$, $\lambda_{\mathrm{em}}=593 / 40 \mathrm{~nm}$ ) as excitation source. Samples were placed on a microscope slide, covered with a cover slip and observed at 200x magnification. The images were captured and stored at $1280 \times 1024$ pixels using the microscope software (NISElements F, Version 4.0, Nikon, Tokyo, Japan). 
Colour

Colour of berry pomace powder was measured in the CIE-Lab colour space with a Luci 100 spectral colorimeter (D65 Xenon lamp, 10 observer; Hach Lange, Düsseldorf, Germany). Lightness $L^{*}$, hue angle $h_{a b}$ and chroma $C^{*}$ were calculated from the colour primaries and used for further interpretation. ${ }^{27}$

\section{Determination of technofunctional properties}

Water activity and sorption isotherms

Equilibrium water activity $a_{w}$ of the pomace powders was measured with a LabMaster-aw benchtop instrument (Novasina AG, Lachen, Switzerland). A Q5000 SA dynamic vapour sorption analyser (TA Instruments, Eschborn, Germany) was used to analyse moisture sorption and desorption at $20^{\circ} \mathrm{C}$. After loading approx. $5 \mathrm{mg}$ sample, relative humidity $\mathrm{RH}$ was kept at $0 \%$ until mass change was less than $0.001 \%$ within 5 min. RH was then increased to $90 \%$ in $10 \%$ steps and, finally, to 95\%; at each level, mass was continuously recorded until no further change was observed ( $<0.01 \%$ for $5 \mathrm{~min}$ ), and desorption isotherms were recorded similarly. The Guggenheim-Anderson-DeBoer (GAB) model was applied for fitting isotherms, with $x$ being the moisture load $\left(\mathrm{g} \mathrm{g}^{-1}\right)$ at a particular $\mathrm{RH}\left(=100 \mathrm{a}_{\mathrm{w}}\right), x_{0}$ being the monolayer moisture load, and $C$ and $k$ referring to the monolayer and multilayer energy constants, respectively: ${ }^{28}$

$x=\frac{x_{0} C k a_{W}}{\left(1-k a_{W}\right)\left(1-k a_{W}+C k a_{W}\right)}$

Water- and oil binding capacity

Water binding capacity (WBC) was determined according to Zahn et al. (2013). ${ }^{29}$ One gram pomace powder was mixed with $30 \mathrm{~mL}$ deionised water, vigorously 
agitated, and kept at $20^{\circ} \mathrm{C}$ for $30 \mathrm{~min}$. The samples were centrifuged at $2000 \mathrm{xg}$ for 10 min. The supernatant was removed, weighed and subjected to dry matter determination (oven method). Initial powder moisture was considered in the calculation of water and dry matter content of the remaining sediment. WBC is defined as $\mathrm{g}$ water that is bound per $\mathrm{g}$ dry pomace powder under these conditions. For swelling capacity determination, $0.2 \mathrm{~g}$ berry pomace powder was weighed into a graduated tube. After adding $10 \mathrm{~mL}$ deionised water and mixing, the tubes were placed in a rack for $18 \mathrm{~h}$ at room temperature. The volume of the swollen pomace powder was read from the graduation, and swelling capacity is further expressed as $\mathrm{mL}$ per g d.m. ${ }^{30}$

To determine the potential to absorb fat, $0.5 \mathrm{~g}$ dried pomace was mixed with $10 \mathrm{~mL}$ canola oil and kept for $18 \mathrm{~h}$ at room temperature. The sample was centrifuged at $10,000 \times \mathrm{g}$ for $30 \mathrm{~min}$, the supernatant discarded and the mass of the pellet determined. In contrast to WBC measurements, where particles remaining in the supernatant were taken into account, the powder particles suspended in oil sedimented completely during centrifugation. Oil absorption capacity (OAC) is defined as $\mathrm{g}$ oil per $\mathrm{g}$ dried pomace powder. ${ }^{31}$

\section{Statistical analysis}

All experiments were carried out in triplicate except dietary fibre content determination $(n=4)$, and total acidity and moisture sorption $(n=2)$. Analysis of variance with subsequent Student-Newman-Keuls post hoc-testing at $P \leq 0.05$ was conducted with SAS University Edition 6p.2 (SAS Institute Inc., Cary, USA).

\section{RESULTS AND DISCUSSION}




\section{Composition of pomace and pomace powders}

The moisture content of fresh pomace ranged from $516.0-764.8 \mathrm{~g} \mathrm{~kg}^{-1}$ (Table 1), and was related to processing conditions. Vagiri \& Jensen ${ }^{32}$ reported that it is especially thermal and enzymatic degradation of pectin that affect juice yield and the distribution of cell compounds between juice and pomace. The companies that manufactured juice from $B C, R C$ and $C B$ treated the respective mashes with pectinase at $50{ }^{\circ} \mathrm{C}$ before pressing. Rowanberry and gooseberry mashes were pressed at room temperature without prior enzymatic treatment so that moisture content was significantly higher (approx. $750 \mathrm{~g} \mathrm{~kg}^{-1}$ ).

Moisture content of dried pomace, containing crushed skins, seeds and stems, was below approx. $50 \mathrm{~g} \mathrm{~kg}^{-1}$. The fat content ranged from $36.1-202.1 \mathrm{~g} \mathrm{~kg}^{-1}$ d.m. and was highest for BC pomace. Pomace fat content largely depends on its seed content; ${ }^{33}$ the relative amount of seeds in the pomace was highest for blackcurrant and redcurrant pomace ( $61 \%$ and $40 \%$, respectively), and lowest for chokeberry and rowanberry ( $20 \%$ and $8.4 \%$, respectively). This is comparable to Sójka et al. ${ }^{34}$ who reported $21.1 \%$ seeds in CB pomace and $57.1-62.1 \%$ in BC pomace. Protein content ranged between $59.7 \mathrm{~g} \mathrm{~kg}^{-1}$ for chokeberry, and $157.1 \mathrm{~g}$ $\mathrm{kg}^{-1}$ for blackcurrant pomace. Literature data are scarce but are, in case of $\mathrm{BC}$, given by $130 \mathrm{~g} \mathrm{~kg}^{-1}$ pomace. ${ }^{33,35}$

The content of insoluble dietary fibre varied between approx. $500-600 \mathrm{~g} \mathrm{~kg}^{-1}$ d.m., and that of SDF between approx. $40-70 \mathrm{~g} \mathrm{~kg}^{-1}$. As published by the Finnish National Institute for Health and Welfare, ${ }^{36}$ total fibre content of fresh berries increases in the order of $\mathrm{GB}<\mathrm{RC}<\mathrm{BC}<\mathrm{RB}$, which is in accordance with the pomace results (Table 1 ). The highest total dietary fibre content is evident for rowanberries (approx. $660 \mathrm{~g} \mathrm{~kg}^{-1}$ ), which might be caused by some remaining pectin due to the 
lack of enzymatic mash treatment before pressing. The fact that the IDF content of skin powder from blackcurrant and chokeberry pomace was specified as being 601 and $666 \mathrm{~g} \mathrm{~kg}^{-1}$ dry matter, respectively, ${ }^{37}$ indicates that skins can be considered as the main fibre sources in pomace.

The acidity of dried pomace was, expressed as tartaric acid equivalents, highest for gooseberry $\left(4.1 \mathrm{~g} \mathrm{~kg}^{-1}\right)$, and lowest for chokeberry $\left(1.1 \mathrm{~g} \mathrm{~kg}^{-1}\right)$, and $\mathrm{pH}$ of the respective suspensions ranged from 3.32 (GB) to approx. 4.5 (BC). The fact that organic acids are transferred into the juice can be taken as explanation for the low acidity of pomace with low moisture (i.e., BC and CB). Residual carbohydrate concentration ranged from $22.0-288.8 \mathrm{~g} \mathrm{~kg}^{-1} \mathrm{~d} . \mathrm{m}$. The observed differences can be attributed to berry composition, the effectiveness of juice extraction, but also to low molecular mass fibre and trace amounts of starch that were not determined as SDF or IDF.

Fresh berry pomace is highly susceptible to microbiological spoilage, and immediate processing is necessary for further use. Total aerobic viable count in fresh pomace ranged from $1.2 \times 10^{3}-1.0 \times 10^{6} \mathrm{cfu} \mathrm{g}^{-1}$, and the yeast and mould count from $1.0 \times 10^{2}-2.0 \times 10^{5} \mathrm{cfu} \mathrm{g}^{-1}$ (Table 2 ). The large differences can be attributed to different contamination levels, but also to different treatments during harvesting, transport and pressing. Since the bacterial count does not exceed $1.0 \times 10^{7} \mathrm{cfu} \mathrm{g}^{-1}$, the standard value of the German Society for Hygiene and Microbiology for cut fruits, all pomace samples can be considered as microbiologically safe. ${ }^{38}$ The recommended limit for yeasts and moulds of $1.0 \times 10^{5} \mathrm{cfu} \mathrm{g}^{-1}$ was, however, exceeded in fresh $B C$ and $C B$ pomace. The time/temperature profile applied during convective drying $\left(60^{\circ} \mathrm{C}\right.$ for $24 \mathrm{~h}$ ) decreased the yeasts and moulds count in all dried pomaces to below the limit of $1.0 \times 10^{4} \mathrm{cfu} \mathrm{g}^{-1} .^{38}$ Depending on fruit variety 
and initial moisture content, total viable count either decreased or increased by approx. one magnitude. For comparison, the acceptable viable count limit for dried sauces is given by $1.0 \times 10^{6} \mathrm{cfu} \mathrm{g}^{-1} .{ }^{38}$ Both product acidity and water activity (highest $a_{w}$ was 0.251 for RC; Table 3 ) imply that there is a low risk of microbiological and enzymatic activity, ${ }^{39,40}$ and that the powders can be considered as stable.

The total polyphenol content can be analysed by relatively simple methods such as the Folin Ciocalteau assay, ${ }^{41}$ or by considering peak areas identified by HPLC-DAD. ${ }^{42}$ In this study, we combined qualitative analysis of MS with total peak areas obtained by DAD. Supporting Information shows representative chromatograms of the extracts at the respective wavelengths (Figure S1). In general, the chromatographic profiles obtained in this study are in agreement with literature data for chokeberry, ${ }^{43}$ redcurrant and blackcurrant, ${ }^{44}$ gooseberry ${ }^{45}$ and rowanberry. ${ }^{46}$ Tentative identification of the individual compounds (Table S1) was based on a combination of the obtained exact mass $(\mathrm{m} / \mathrm{z})$, MS fragmentation pattern and the retention time of the respective peaks.

As shown in Figure 1, chokeberry has the highest total phenolic content as measured at $280 \mathrm{~nm}$, which is because of the high content of anthocyanins. The anthocyanin content is approx. five times higher than that of blackcurrant pomace, which showed the second-highest values. Compounds detected at $520 \mathrm{~nm}$ (Figure 1S: peaks 11, 12, 15 and 29) were identified as cyanidin 3-galactoside, cyanidin 3glucoside, cyanidin 3-arabinoside and cyanidin 3-xyloside (Table S1).47,48 Chlorogenic acid and chlorogenic acid derivates $(\mathrm{m} / \mathrm{z} 353)$ were detected in high intensities (peaks 1 and 5 in Figure S1). At 520 nm, nine peaks were detected in blackcurrant extract compared to four peaks in redcurrant which explains the intense colour of blackcurrant. Free and glycoside forms of quercetin and 
kaempferol (Table S1) are the main flavonoids detected in blackcurrant and redcurrant. ${ }^{44,49}$ Gooseberry has a variety of flavonoids and anthocyanins; however, their abundance is low compared to other berries (see total peak area at $280 \mathrm{~nm}$ ). Although the colour of gooseberry is orange, ten peaks were detected at $520 \mathrm{~nm}$ representing anthocyanins and confirmed by the exact $m / z$ and previous studies. ${ }^{45}$ In contrast, in rowanberry one peak only was detected at $520 \mathrm{~nm}$ with $\mathrm{m} / z$ 449, identified as cyanidin-3-galactoside. On the other hand, rowanberry is rich in chlorogenic acid and its derivates (peaks 1, 5, 6 and 33). Proanthocyanins in dimeric or trimeric form generally show low peak intensities. To overcome this drawback, ion chromatograms were used to detect this group of compounds using the exact masses of $\mathrm{m} / \mathrm{z} 577.134$ and 865.198 for dimers and trimers, respectively. Few peaks (peaks 4, 26, 30 and 41 ) where detected at low intensity compared to flavonoids and anthocyanins.

\section{Physical and technofunctional properties}

Despite similar milling conditions, the particle size median differed significantly (Table 3) with $x_{50}$ values ranging between $86.4 \mu \mathrm{m}(\mathrm{CB})$ and $112.7 \mu \mathrm{m}(\mathrm{BC}) . \mathrm{CB}$ and RB are Rosaceae whereas BC, RC and GB of the Grossulariaceae genus Ribes are botanically classified as berries. It can be presumed that Ribes seeds are less susceptible to fracture so that higher stresses are needed to obtain a comparable particle size. With regard to the $x_{90}$ percentile, between-variety differences were less prominent.

Colour of the pomace powders ranged from dark purple $(\mathrm{CB})$ to dark yellow (RB), depending on berry colour (Figure 2). It is the anthocyanins with their antioxidant activity that are mainly responsible for the colour of berries. ${ }^{50}$ In 
blackcurrant, for example, the main anthocyanins are delphinidin-3-glucoside, delphinidin-3-rutinoside, cyanidine-3-glucoside and cyanidin-3-rutinoside. ${ }^{9}$ The hue angle was in the red domain for $C B\left(h_{a b}=20.1^{\circ}\right)$ and increased up to $h_{a b}=69.2^{\circ}$ for RB pomace; colour saturation ranged from $C^{*}=8.3(C B)$ to $31.5(R B)$.

As can be seen from the FESEM pictures (Figure 3), the pomace powders RC and GB contain particles that still show the cellular structure of the original fruit. Specifically, in RC pomace powder particles, even a high degree of cellular turgor was observed, which could be related to the significantly higher moisture content. On the other hand, the particles of RB and $\mathrm{CB}$, which had a low moisture content, appeared unstructured without exhibiting a well-defined cellular structure. The BC particles had an intermediate structural integrity; the presence of cells or cellular structures can be hardly observed in this powder.

In addition, the $\mathrm{BC}$ particles showed a cohesive and fused network structure. This structure is in line with compositional results since this pomace powder had the highest protein and fat content. Thus, the presence of protein seems to favour the structural network organization of the particles, while the fat would be acting as a binder that prevents fracture of the particles into smaller pieces. This could be the reason for their significantly larger size if compared to the other pomace powders, as it is summarized in Table 3. On the other hand, the pomace powder particles of RB and CB did not show a network structure but seemed to be built by small and unstructured pieces, superimposed one on the other. This lack of cohesive structure can be related to the significantly lower contents of protein and fat that were evident for these pomace powders. Bright field microscopic images of BC powder pomace (Figure 4, left) showed cohesive particles forming a network structure, as it was also observed by 
FESEM. Small particles seem to be joined intimately to form larger particles.

However, in CB pomace powder, small isolated particles of different shape and size are evident, with the reddish coloration being due to their content in anthocyanidins. Although information is scarce, it is known that the derivatives of the cyanidins are fluorescent. ${ }^{51}$ In this sense, it was observed that $C B$ pomace powder (Figure 4, right) exhibited a higher fluorescence intensity than BC pomace powder. This is in agreement with the results obtained for polyphenol content (Figure 1), which showed significantly higher contents for CB pomace powder. Blackcurrant pomace exhibited the lowest water binding capacity $\left(3.2 \mathrm{~g} \mathrm{~g}^{-1}\right.$ d.m.), most likely because of degraded pectin and high fat content, ${ }^{52}$ and similar water binding capacities are reported in the literature. ${ }^{53} \mathrm{RB}$ and GB that were not enzymatically treated before pressing showed significantly higher WBCs (approx. $4.7 \mathrm{~g} \mathrm{~g}^{-1}$ ). Furthermore, the hydration properties of fibres with a high content of primary cell wall components (hemicellulose, pectin) are enhanced compared to fibre with a high content of secondary cell wall components (cellulose, lignin) that are mainly present in seeds and stems. ${ }^{54}$ According to Rosell et al. ${ }^{55}$ a low particle size is responsible for low WBC, which is true for chokeberry with its low water binding capacity ( $3.85 \mathrm{~g} \mathrm{~g}^{-1} \mathrm{~d} . \mathrm{m}$.). In contrast larger surface areas favour water adsorption, as can be seen from the comparatively high swelling capacity of this variety $\left(6.7 \mathrm{ml} \mathrm{g}^{-1}\right.$ d.m.). Swelling capacity of other pomace powders decreased in the same order as WBC. Oil absorption capacity is a measure of oil retention in foods, and rather depends on particle porosity than on chemical composition or molecular affinity to oil. ${ }^{52,56}$ Among the pomace varieties OAC did not differ significantly but ranged from $1.91-2.27 \mathrm{~g} \mathrm{~g}^{-1} \mathrm{~d} . \mathrm{m}$. , a similar range as observed for pineapple pomace $\left(2.01 \mathrm{~g} \mathrm{~g}^{-1}\right) .{ }^{57}$ For comparison, wheat flour $\left(0.85 \mathrm{~g} \mathrm{~g}^{-1}\right)$ and citrus 
fibres $\left(1.2-1.8 \mathrm{~g} \mathrm{~g}^{-1}\right)$ show lower, mango peels and apple fibres higher oil absorption capacities ( 2.7 and $3.36 \mathrm{~g} \mathrm{~g}^{-1}$, respectively). ${ }^{58,59}$

As stated by Chen et al. ${ }^{60}$ the WBC, determined by the centrifugation method, is appropriate to characterise foods with $a_{w}>0.98$ but sorption isotherms are recommended as source of supplementary information concerning water retention. Moisture adsorption and desorption isotherms (Figure 5) show a moderate uptake of moisture for up to $60 \% \mathrm{RH}$, resulting in respective equilibrium moisture loads of below $100 \mathrm{~g} \mathrm{~kg}^{-1}$. It can be assumed that chemisorption plays a minor role whereas capillary and swelling effects, that mean moisture binding in small and subsequently in larger pores, predominate. The pronounced increase of moisture adsorption above $80 \% \mathrm{RH}$ can be attributed to sugar crystals that start to dissolve at this humidity. Differences in moisture uptake between berry varieties become pronounced at high relative humidity. However, the impact of particle size of the powders is less prominent as can be seen from black currant (Supporting information, Figure S2). Doubling the $\mathrm{x}_{50}(112.7 \mu \mathrm{m}$ to $243.2 \mu \mathrm{m})$ and $\mathrm{x}_{90}(271.3$ $\mu \mathrm{m}$ to $563.3 \mu \mathrm{m}$ ) showed no significant differences in moisture adsorption below $30 \% \mathrm{RH}$ and above $80 \% \mathrm{RH}$.

The application of mathematical models to isotherms may help detecting details about interactions between moisture and sorbent. GAB modelling resulted in $R^{2}>0.997$ for adsorption (A) and $>0.992$ for desorption (D), with excellent approximation up to $90 \% \mathrm{RH}$ (Table 4). Except for BC (Typ II, $C k>2$ ), the adsorption follows Typ III isotherms $(C k<2)$ of Brunauer's classification while all desorption curves showed sigmoidal shape. ${ }^{61}$ The hysteresis areas indicate that, for drying processes, either lower $\mathrm{RH}$ or higher temperatures are essential to gain comparable residual moisture. Moisture load at monolayer adsorption $\mathrm{x}_{0}$ was lowest 
for $B C\left(42.29 \mathrm{~g} \mathrm{~kg}^{-1}\right)$ and highest for $\mathrm{CB}\left(65.74 \mathrm{~g} \mathrm{~kg}^{-1}\right)$ which can be linked to volume-based specific surface areas that increased in the same order (Table 3). Differences between $A$ and $D$ isotherms become apparent for the monolayer enthalpy constant $C$ (monolayer binding forces during desorption are many times higher than during adsorption; GB 3.7 fold, RC 17 fold), whereas variations of berry variety are negligible. The transition of mono- to multilayer adsorption is unincisive (except for BC), which becomes apparent from the low $C$ and the absent bend of the sorption isotherms at $10 \% \mathrm{RH} . k$ which points on multilayer interactions between moisture and sorbent is lower during adsorption, indicating weaker binding forces. BC shows however an inverse behaviour, with $k$ differing significantly from those of other powders. Besides surface characteristics (less porous surface area), a reduced moisture sorption can be linked to low carbohydrate contents. As described by Witczak et al. ${ }^{62}$ sugar fortified orange peel showed a sharp increase of moisture uptake above $60 \% \mathrm{RH}$, and significantly more moisture was adsorbed than by dried peels. WBC of fruits is mainly determined by sugar content and surface characteristics, whereby it turned out that convective drying resulted in minor porosity and hygroscopicity than other drying methods. ${ }^{63}$ Compared to other fruits and their by-products, powders from berry pomace adsorb less moisture at $20 / 25^{\circ} \mathrm{C}$, due to processing and compositional properties. ${ }^{62,64,65}$ As regards presumptive applications of dried berry pomace as food ingredient, a wide range of food systems is possible, particularly sweet or savoury baked products. Depending on berry variety and substitution level, the powders will have an impact on colour, rheological properties, texture and nutritional value. ${ }^{17,18,66}$

\section{CONCLUSIONS}


Drying and subsequent milling of berry pomace resulted in colour-intense fruit powders with considerable amounts of polyphenols. Pomaces of Ribes genus (BC, RC, GB) were found to contain more protein, and higher amounts of seeds and therefore fat compared to chokeberry and rowanberry. These properties are important for interpreting differences in particle size. As observed by FESEM and laser diffraction, powder particles with a less intact cellular structure showed high specific surface areas. Moisture sorption was dominated by capillary effects, but was also influenced by the content of carbohydrates. As particle size seems to have a significant impact on hydration properties, further studies that show how processing conditions influence pomace powder characteristics would be valuable.

\section{ACKNOWLEDGEMENTS}

The research project was approved during the $2^{\text {nd }}$ SUSFOOD ERA-Net call (www.susfood-era.net). The funding of the project, assured through the national partner organisations, is gratefully acknowledged: Federal Ministry of Education and Research via PTJ in Germany (grant 031B0004), INIA in Spain and FORMAS in Sweden.

\section{REFERENCES}

1 EFSA Panel on Dietetic Products, Nutrition and Allergies, Scientific Opinion on Dietary Reference Values for carbohydrates and dietary fibre. EFSA J 8:1462$1538(2010)$.

2 Elleuch M, Bedigian D, Roiseux O, Besbes S, Blecker C and Attia H, Dietary fibre and fibre-rich by-products of food processing: Characterisation, 
technological functionality and commercial applications: A review. Food Chem 124: 411-421 (2011).

3 Ktenioudaki A and Gallagher E, Recent advances in the development of highfibre baked products. Trends Food Sci Technol. 28:4-14 (2012).

4 McKee LH and Latner TA, Underutilized sources of dietary fiber: A review. Plant Foods Hum Nutr 55:285-304 (2000).

5 Dhillon GS, Kaur S and Brar SK, Perspective of apple processing wastes as lowcost substrates for bioproduction of high value products: A review. Renew Sustain Energy Rev 27:789-805 (2013).

6 Kohajdová Z, Karovičová J and Jurasová M, Influence of grapefruit dietary fibre rich powder on the rheological characteristics of wheat flour dough and on biscuit quality. Acta Aliment 42:91-101 (2013).

7 Struck S, Plaza M, Turner C and Rohm H, Berry pomace - a review of processing and chemical analysis of its polyphenols. Int J Food Sci Technol 51:1305-1318 (2016).

8 Skrede G, Wrolstad RE and Durst RW, Changes in anthocyanins and polyphenolics during juice processing of highbush blueberries (Vaccinium corymbosum L.). J Food Sci 65:357-364 (2000).

9 Holtung L, Grimmer S and Aaby K, Effect of processing of black currant pressresidue on polyphenol composition and cell proliferation. J Agric Food Chem 59:3632-3640 (2011).

10 Oszmiański J and Wojdylo A. Aronia melanocarpa phenolics and their antioxidant activity. Eur Food Res Technol 221:809-813 (2005). 
11 Viuda-Martos M, López-Marcos MC, Fernández-López J, Sendra E, López-Vargas JH and Pérez-Álvarez JA, Role of fiber in cardiovascular diseases: A review. Compr Rev Food Sci Food Saf 9:240-258 (2010).

12 Eim VS, Simal S, Rosselló C and Femenia A, Effects of addition of carrot dietary fibre on the ripening process of a dry fermented sausage (sobrassada). Meat Sci 80:173-182 (2008).

13 Sójka M, Miszczak A, Sikorski P, Zagibajło K, Karlińska E and Kosmala M, Pesticide residue levels in strawberry processing by-products that are rich in ellagitannins and an assessment of their dietary risk to consumers. NFS J 1:31$37(2015)$

14 European Commission, EU Pesticides database 2017. http://ec.europa.eu/food [5 December 2017]

15 Ortelli D, Edder P and Corvi C, Multiresidue analysis of 74 pesticides in fruits and vegetables by liquid chromatography-electrospray-tandem mass spectrometry. Anal Chim Acta 520:33-45 (2004)

16 Rohm H, Brennan C, Turner C, Günther E, Campbell G, Hernando I et al., Adding value to fruit processing waste: Innovative ways to incorporate fibers from berry pomace in baked and extruded cereal-based foods-A SUSFOD project. Foods 4:690-697 (2015).

17 Schmidt C, Geweke I, Struck S, Zahn S and Rohm H, Blackcurrant pomace from juice processing as partial flour substitute in savoury crackers: dough characteristics and product properties. Int J Food Sci Technol 53:237-245 (2018). 
18 Tarrega A, Quiles A, Morell P, Fiszman S and Hernando I, Importance of consumer perceptions in fiber-enriched food products. A case study with sponge cakes. Food Funct 8:574-583 (2017).

19 Sporin M, Avbelj M, Kovac B and Mozina SS, Quality characteristics of wheat flour dough and bread containing grape pomace flour. Food Sci Technol Int 24:251-263 (2018)

20 Choi Y-S, Kim YB, Hwang KE, Song DH, Ham YK, Kim HW, Sung JM and Kim CJ, Effect of apple pomace fiber and pork fat levels on quality characteristics of uncured, reduced-fat chicken sausages. Poultry Sci 95:1465-1471 (2016)

21 Hilz H, Bakx EJ, Schols HA and Voragen AGJ, Cell wall polysaccharides in black currants and bilberries-characterisation in berries, juice, and press cake. Carbohydr Polym 59:477-488 (2005).

22 Tournas VH and Katsoudas E, Mould and yeast flora in fresh berries, grapes and citrus fruits. Int J Food Microbiol 105:11-17 (2005).

23 Sivam AS, Sun-Waterhouse D, Perera CO and Waterhouse GIN, Exploring the interactions between blackcurrant polyphenols, pectin and wheat biopolymers in model breads; a FTIR and HPLC investigation. Food Chem131:802-810 (2012).

24 Lee SC, Prosky L, De Vries JW, Determination of total, soluble and insoluble dietary fiber in foods. Enzymatic-gravimetric method, MES-TRIS Buffer: Collaborative study. J AOAC Int 75:395-416 (1992).

25 Plaza M, Abrahamsson V and Turner C, Extraction and neoformation of antioxidant compounds by pressurized hot water extraction from apple byproducts. J Agric Food Chem 61:5500-5510 (2013). 
26 Hernández-Carrión M, Sanz T, Hernando I, Llorca E, Fiszman SM and Quiles A, New formulations of functional white sauces enriched with red sweet pepper. A rheological, microstructural and sensory study. Eur Food Res Technol 240:1187-1202 (2015).

27 Rohm H and Jaros D, Colour of hard cheese: 1. Description of colour properties and effects of maturation. Z Lebensm Unters -Forsch 203:241-244 (1996).

28 Mutungi C, Schuldt S, Onyango C, Schneider Y, Jaros D and Rohm H, Dynamic moisture sorption characteristics of enzyme-resistant recrystallized Cassava starch. Biomacromol 12:660-671 (2011).

29 Zahn S, Forker A, Krügel L and Rohm H, Combined use of rebaudioside A and fibres for partial sucrose replacement in muffins. LWT - Food Sci Technol 50:695-701 (2013).

30 Robertson JA, de Monredon FD, Dysseler P, Guillon F, Amado R and Thibault JF, Hydration properties of dietary fibre and resistant starch: a European collaborative study. LWT - Food Sci Technol 33:72-79 (2000).

31 Raghavendra SN, Ramachandra Swamy SR, Rastogi NK, Raghavarao KSMS, Kumar S and Tharanathan RN, Grinding characteristics and hydration properties of coconut residue: A source of dietary fiber. J Food Eng 72:281286 (2006).

32 Vagiri $M$ and Jensen $M$, Influence of juice processing factors on quality of black chokeberry pomace as a future resource for colour extraction. Food Chem 217:409-417 (2017).

33 Sójka M and Król B, Composition of industrial seedless black currant pomace. Eur Food Res Technol 228:597-605 (2008). 
34 Sójka M, Kołodziejczyk K and Milala J, Polyphenolic and basic chemical composition of black chokeberry industrial by-products. Ind Crops Prod 51:77$86(2013)$

35 U.S. Department of Agriculture, Agricultural Research Service, USDA National Nutrient Database for Standard Reference. Release 28. Beltsville: Nutrient Data Laboratory. https://www.ars.usda.gov/ [24 November, 2017]

36 National Institute for Health and Welfare, Fineli, Finnish food composition database. Release 18. Helsinki: Nutrition Unit. https://fineli.fi/fineli/en/index [24 November, 2017]

37 Wawer I, Wolniak M and Paradowska K, Solid state NMR study of dietary fiber powders from aronia, bilberry, black currant and apple. Solid State Nucl Magn Reson 30:106-113 (2006).

38 German Society for Hygiene and Microbiology, Mikrobiologische Richt- und Warnwerte zur Beurteilung von Lebensmitteln online. https://www.dghm-richtwarnwerte.de/de [30 November, 2017]

39 Fazaeli M, Emam-Djomeh Z, Kalbasi Ashtari A and Omid M, Effect of spray drying conditions and feed composition on the physical properties of black mulberry juice powder. Food Bioprod Process 90:667-675 (2012).

40 Tapia MS, Alzamora SM and Chirife J, Effects of water activity (aw) on microbial stability: As a hurdle in food preservation, in Water Activity in Foods, ed. by Barbosa-Canovas GV, Fontana AJ, Schmidt SJ and Labuza TP. Blackwell Publishing, Oxford, pp. 230-272 (2007).

41 Margraf T, Karnopp AR, Rosso ND and Granato D. Comparison between FolinCiocalteu and Prussian Blue assays to estimate the total phenolic content of juices and teas using 96-well microplates. J Food Sci 80:C2397-C2403 (2015). 
42 Sajewicz M, Staszek D, Wróbel MS, Waksmundzka-Hajnos M and Kowalska T. The HPLC/DAD fingerprints and chemometric analysis of flavonoid extracts from the selected sage (Salvia) species. Chromat Res Int, article 230903 (2012).

43 Ćujić N, Savikin K, Miloradovic Z, Ivanov M, Vajic UJ, Karanovic D ... and Mihailovic-Stanojevic N Characterization of dried chokeberry fruit extract and its chronic effects on blood pressure and oxidative stress in spontaneously hypertensive rats. J Functional Foods 44:330-339 (2018).

44 Gavrilova V, Kajdžanoska M, Gjamovski V and Stefova M. Separation, characterization and quantification of phenolic compounds in blueberries and red and black currants by HPLC-DAD-ESI-MSn. J Agric Food Chem 59:4009$4018(2011)$

45 Bochi VC, Godoy HAT and Giusti MM. Anthocyanin and other phenolic compounds in Ceylon gooseberry (Dovyalis hebecarpa) fruits. Food Chem 176:234-243 (2015).

46 Kylli P, Nohynek L, Puupponen-Pimiä R, Westerlund-Wikström B, McDougall G, Stewart D, et al., Rowanberry phenolics: Compositional analysis and bioactivities. J Agric Food Chem 58:11985-11992 (2010).

47 Bräunlich M, Slimestad R, Wangensteen H, Brede C, Malterud K and Barsett $\mathrm{H}$, Extracts, anthocyanins and procyanidins from Aronia melanocarpa as radical scavengers and enzyme inhibitors. Nutrients 5:663-678 (2013)

48 Nakajima J, Tanaka I, Seo S, Yamazaki M and Saito K, LC/PDA/ESI-MS profiling and radical scavenging activity of Anthocyanins in various berries. J Biomed Biotechnol 2004:241-247 (2004). 
49 Borges G, Degeneve A, Mullen W and Crozier A. Identification of flavonoid and phenolic antioxidants in black currants, blueberries, raspberries, red currants, and cranberries. J Agric Food Chem 58:3901-3909 (2010).

50 Laroze LE, Díaz-Reinoso B, Moure A, Zúñiga ME, Domínguez H, Extraction of antioxidants from several berries pressing wastes using conventional and supercritical solvents. Eur Food Res Technol. 231:669-677 (2010)

51 Rakic V, Ota A, Skrt M, Miljkovic M, Kostic D, Sokolovic D, et al., Investigation of fluorescence properties of cyanidin and cyanidin 3-o- $\beta$-glucopyranoside. Hem Ind 69:155-163 (2015).

52 Raghavendra SN, Rastogi NK, Raghavarao KSMS and Tharanathan RN, Dietary fiber from coconut residue: effects of different treatments and particle size on the hydration properties. Eur Food Res Technol 218:563-567 (2004).

53 Kosmala M, Kołodziejczyk K, Markowski J, Mieszczakowska M, Ginies C and Renard CMGC, Co-products of black-currant and apple juice production: Hydration properties and polysaccharide composition. LWT - Food Sci Technol 43:173-180 (2010).

54 Guillon F and Champ M, Structural and physical properties of dietary fibres, and consequences of processing on human physiology. Food Res Int 33:233-245 (2000).

55 Rosell CM, Santos E and Collar C, Physico-chemical properties of commercial fibres from different sources: A comparative approach. Food Res Int 42:176184 (2009).

56 Yalegama LLWC, Nedra Karunaratne D, Sivakanesan R and Jayasekara C, Chemical and functional properties of fibre concentrates obtained from byproducts of coconut kernel. Food Chem 141:124-130 (2013). 
57 Selani MM, Brazaca SGC, dos Santos Dias CT, Ratnayake WS, Flores RA and Bianchini A, Characterisation and potential application of pineapple pomace in an extruded product for fibre enhancement. Food Chem 163:23-30 (2014).

58 Figuerola F, Hurtado ML, Estévez AM, Chiffelle I and Asenjo F, Fibre concentrates from apple pomace and citrus peel as potential fibre sources for food enrichment. Food Chem 91:395-401 (2005).

59 Kohajdová Z, Karovičová J, Magala M and Kuchtová V, Effect of apple pomace powder addition on farinographic properties of wheat dough and biscuits quality. Chem Pap 68:1059-1065 (2014).

60 Chen JY, Piva M and Labuza TP, Evaluation of water binding capacity (WBC) of food fiber sources. J Food Sci 49:59-63 (1984).

61 Timmermann EO, A B. E. T.-like three sorption stage isotherm. J Chem Soc Faraday Trans Phys Chem Condens Phases 85:1631 (1989).

62 Witczak T, Witczak M, Socha R, Stepien A and Grzesik M, Candied orange peel produced in solutions with various sugar compositions: Sugar composition and sorption properties of the product. J Food Process Eng 40:e12367 (2017).

63 Tsami E, Krokida MK and Drouzas AE, Effect of drying method on the sorption characteristics of model fruit powders. J Food Eng 38:381-392 (1998).

64 Oliveira DEC de, Resende O, Costa LM, Ferreira Júnior WN and Igor OFS, Hygroscopicity of baru (Dipteryx alata Vogel) fruit. Rev Bras Eng Agríc E Ambient 21:279-284 (2017).

65 Ribeiro LC, da Costa JMC and Afonso MRA, Hygroscopic behavior of lyophilized acerola pulp powder. Rev Bras Eng Agríc E Ambient 20:269-274 (2016). 
66 Struck S, Straube D, Zahn S and Rohm H, Interaction of wheat macromolecules and berry pomace in model dough: Rheology and microstructure. J Food Eng 223:109-115 (2018) 
Table 1. Proximate composition of berry pomace powder.

\begin{tabular}{|c|c|c|c|c|c|}
\hline Parameter & Blackcurrant & Redcurrant & Gooseberry & Rowanberry & Chokeberry \\
\hline Pomace moisture $\left(\mathrm{g} \mathrm{kg}^{-1}\right)$ & $516.0 \pm 0.8^{e}$ & $621.5 \pm 6.9^{c}$ & $748.2 \pm 8.3^{b}$ & $764.8 \pm 7.2^{\mathrm{a}}$ & $549.8 \pm 3.2^{d}$ \\
\hline Powder moisture $\left(\mathrm{g} \mathrm{kg}^{-1}\right)$ & $34.3 \pm 0.1^{c}$ & $51.8 \pm 0.2^{\mathrm{a}}$ & $50.5 \pm 0.4^{b}$ & $26.9 \pm 0.1^{d}$ & $27.2 \pm 0.2^{\mathrm{d}}$ \\
\hline Fat $\left(\mathrm{g} \mathrm{kg}^{-1}\right)^{*}$ & $202.1 \pm 2.2^{\mathrm{a}}$ & $142.3 \pm 3.5^{b}$ & $109.3 \pm 0.2^{c}$ & $39.7 \pm 1.3^{d}$ & $36.1 \pm 1.1^{\mathrm{d}}$ \\
\hline Protein $\left(\mathrm{g} \mathrm{kg}^{-1}\right)^{*}$ & $157.1 \pm 0.6^{\mathrm{a}}$ & $117.6 \pm 2.7^{c}$ & $124.0 \pm 0.4^{b}$ & $70.9 \pm 0.8^{d}$ & $59.7 \pm 1.1^{\mathrm{e}}$ \\
\hline Ash $\left(\mathrm{g} \mathrm{kg}^{-1}\right)^{*}$ & $26.6 \pm 0.3^{d}$ & $30.0 \pm 0.6^{b}$ & $34.0 \pm 0.2^{\mathrm{a}}$ & $28.4 \pm 0.6^{c}$ & $19.2 \pm 0.0^{\mathrm{e}}$ \\
\hline $\operatorname{SDF}\left(\mathrm{g} \mathrm{kg}^{-1}\right)^{*}$ & $39.7 \pm 2.9^{b}$ & $70.0 \pm 2.9^{a}$ & $70.4 \pm 3.7^{\mathrm{a}}$ & $76.8 \pm 7.3^{\mathrm{a}}$ & $70.4 \pm 13.5^{a}$ \\
\hline IDF $\left(\mathrm{g} \mathrm{kg}^{-1}\right)^{*}$ & $551.6 \pm 16.5^{\mathrm{b}}$ & $510.8 \pm 8.1^{\mathrm{cd}}$ & $495.6 \pm 9.4^{d}$ & $594.9 \pm 15.3^{a}$ & $524.6 \pm 11.0^{c}$ \\
\hline Titratable acid $\left(\mathrm{g} \mathrm{kg}^{-1}\right)^{*}$ & $0.9 \pm 0.0^{\mathrm{e}}$ & $2.8 \pm 0.1^{\mathrm{b}}$ & $4.1 \pm 0.1^{\mathrm{a}}$ & $2.3 \pm 0.0^{c}$ & $1.2 \pm 0.0^{\mathrm{d}}$ \\
\hline Carbohydrates $\left(\mathrm{g} \mathrm{kg}^{-1}\right)^{*}$ & 22.0 & 126.5 & 162.6 & 187.1 & 288.8 \\
\hline
\end{tabular}

Mean values ( \pm standard deviation, $n=3$ ) in a row with different superscripts differ significantly $(P<0.05){ }^{*}$, dry matter related content. SDF - soluble dietary fibre, IDF - insoluble dietary fibre 
Table 2. Microbial counts of fresh and dried berry pomace.

\begin{tabular}{lccccc}
\hline \multirow{2}{*}{$\begin{array}{l}\text { Berry pomace } \\
\text { variety }\end{array}$} & \multicolumn{2}{c}{ Total viable count $\left(\mathrm{cfu} \mathrm{g}^{-1}\right)$} & & \multicolumn{2}{c}{ Yeasts and moulds $\left(\mathrm{cfu} \mathrm{g}^{-1}\right)$} \\
\cline { 2 - 3 } \cline { 5 - 5 } & Fresh pomace & Dried pomace & & Fresh pomace & Dried pomace \\
\hline Blackcurrant & $1.0 \cdot 10^{6}$ & $1.6 \cdot 10^{3}$ & & $1.7 \cdot 10^{5}$ & $1.2 \cdot 10^{3}$ \\
Redcurrant & $1.2 \cdot 10^{3}$ & $6.1 \cdot 10^{4}$ & & $2.3 \cdot 10^{2}$ & $2.9 \cdot 10^{2}$ \\
Gooseberry & $1.3 \cdot 10^{3}$ & $8.8 \cdot 10^{4}$ & & $1.0 \cdot 10^{2}$ & $1.0 \cdot 10^{2}$ \\
Rowanberry & $2.0 \cdot 10^{5}$ & $6.3 \cdot 10^{5}$ & & $1.1 \cdot 10^{2}$ & $1.0 \cdot 10^{2}$ \\
Chokeberry & $2.0 \cdot 10^{5}$ & $2.1 \cdot 10^{4}$ & & $2.0 \cdot 10^{5}$ & $2.3 \cdot 10^{2}$ \\
\hline
\end{tabular}


Table 3. Physical and technofunctional properties of berry pomace powder.

\begin{tabular}{|c|c|c|c|c|c|}
\hline Parameter & Blackcurrant & Redcurrant & Gooseberry & Rowanberry & Chokeberry \\
\hline $\begin{array}{l}\text { Relative seed } \\
\text { content }(\%)\end{array}$ & $61.0 \pm 1.0^{\mathrm{a}}$ & $40.4 \pm 5.3^{b}$ & $34.2 \pm 1.4^{c}$ & $8.4 \pm 0.2^{\mathrm{e}}$ & $22.1 \pm 0.1^{\mathrm{d}}$ \\
\hline \multicolumn{6}{|l|}{ Particle size $(\mu \mathrm{m})$} \\
\hline$x_{50}$ & $112.7 \pm 2.4^{\mathrm{a}}$ & $107.2 \pm 2.6^{\mathrm{b}}$ & $095.4 \pm 2.9^{c}$ & $095.1 \pm 1.6^{c}$ & $86.4 \pm 1.1^{d}$ \\
\hline$X_{90}$ & $271.3 \pm 9.9^{a}$ & $262.7 \pm 14.4^{a}$ & $244.1 \pm 2.6^{b}$ & $263.1 \pm 5.3^{a}$ & $239.9 \pm 2.5^{b}$ \\
\hline $\begin{array}{l}\text { Specific surface } \\
\text { area }\left(\mathrm{m}^{2} \mathrm{~mL}\right)\end{array}$ & $0.08 \pm 0.01$ & $0.09 \pm 0.00$ & $0.14 \pm 0.04$ & $0.24 \pm 0.00$ & $0.28 \pm 0.01$ \\
\hline Water activity (-) & $0.100 \pm 0.001^{\mathrm{d}}$ & $0.251 \pm 0.001^{\mathrm{a}}$ & $0.169 \pm 0.001^{b}$ & $0.112 \pm 0.002^{c}$ & $0.091 \pm 0.001^{e}$ \\
\hline $\begin{array}{l}\text { Water binding } \\
\text { capacity ( } \mathrm{g} \mathrm{g}^{-1} \text { dry } \\
\text { matter) }\end{array}$ & $03.20 \pm 0.20^{c}$ & $04.06 \pm 0.08^{b}$ & $04.65 \pm 0.18^{a}$ & $04.74 \pm 0.61^{a}$ & $3.85 \pm 0.06^{b}$ \\
\hline $\begin{array}{l}\text { Swelling capacity } \\
\text { ( } \mathrm{mL} \mathrm{g}^{-1} \text { dry matter) }\end{array}$ & $05.50 \pm 0.15^{c}$ & $06.12 \pm 0.39^{b c}$ & $06.14 \pm 0.17^{b c}$ & $07.09 \pm 0.19^{a}$ & $6.70 \pm 0.43^{\mathrm{ab}}$ \\
\hline $\begin{array}{l}\text { Fat absorption } \\
\text { capacity ( } \mathrm{g} \mathrm{g}^{-1} \text { dry } \\
\text { matter) }\end{array}$ & $02.00 \pm 0.09^{a}$ & $01.94 \pm 0.15^{a}$ & $02.06 \pm 0.17^{a}$ & $02.27 \pm 0.13^{a}$ & $1.91 \pm 0.12^{a}$ \\
\hline
\end{tabular}

Mean values ( \pm standard deviation, $n=3$ ) in a row with different superscripts differ significantly $(P<0.05)$. 
Table 4. GAB Coefficients of fitted sorption isotherms of berry pomace powder.

\begin{tabular}{lllllll}
\hline Parameter & Blackcurrant & Redcurrant & Gooseberry & Rowanberry & Chokeberry \\
\hline$x_{0}$ & A $^{*}$ & $42.29 \pm 0.86^{\mathrm{c}}$ & $52.69 \pm 2.45^{\mathrm{b}}$ & $55.77 \pm 3.16^{\mathrm{b}}$ & $54.20 \pm 2.63^{\mathrm{b}}$ & $65.74 \pm 1.32^{\mathrm{a}}$ \\
$\left(\mathrm{g} \mathrm{kg}^{-1}\right)$ & $\mathrm{D}$ & $47.82 \pm 0.96^{\mathrm{ab}}$ & $44.98 \pm 1.52^{\mathrm{bc}}$ & $42.58 \pm 0.03^{\mathrm{c}}$ & $47.47 \pm 1.04^{\mathrm{ab}}$ & $51.66 \pm 0.02^{\mathrm{a}}$ \\
$k$ & A & $0.886 \pm 0.002^{\mathrm{c}}$ & $0.914 \pm 0.002^{\mathrm{ab}}$ & $0.935 \pm 0.007^{\mathrm{a}}$ & $0.920 \pm 0.007^{\mathrm{ab}}$ & $0.909 \pm 0.002^{\mathrm{b}}$ \\
& D & $0.860 \pm 0.003^{\mathrm{c}}$ & $0.929 \pm 0.004^{\mathrm{b}}$ & $0.968 \pm 0.001^{\mathrm{a}}$ & $0.935 \pm 0.002^{\mathrm{b}}$ & $0.934 \pm 0.000^{\mathrm{b}}$ \\
$\mathrm{C}$ & A $^{*}$ & $03.75 \pm 0.01^{\mathrm{a}}$ & $01.62 \pm 0.34^{\mathrm{b}}$ & $01.49 \pm 0.19^{\mathrm{b}}$ & $01.90 \pm 0.04^{\mathrm{b}}$ & $01.28 \pm 0.04^{\mathrm{b}}$ \\
& D & $16.03 \pm 0.62^{\mathrm{ab}}$ & $27.63 \pm 7.45^{\mathrm{a}}$ & $05.51 \pm 0.55^{\mathrm{b}}$ & $11.04 \pm 2.42^{\mathrm{b}}$ & $08.76 \pm 0.21^{\mathrm{b}}$ \\
$R^{2}$ & A & 0.997 & 0.999 & 0.999 & 0.999 & 0.999 \\
& D & 0.997 & 0.992 & 0.999 & 0.997 & 0.997 \\
\hline
\end{tabular}

Model ranges are $10 \leq \mathrm{RH}(\%) \leq 90, \mathrm{~A}$ - Adsorption, D - Desorption, $x_{0}$ - monolayer moisture load, $C$ monolayer energy constant, $k$-multilayer energy constant.

*Adsorption isotherms differ significantly from Desorption isotherms $(P<0.05)$. Mean values $( \pm$ deviation, $n=2)$ in a row with different superscripts differ significantly $(P<0.05)$. 


\section{Figure captions}

Figure 1. Polyphenol content of freeze-dried berry pomace, representing total polyphenols at $280 \mathrm{~nm}$, flavonols at $350 \mathrm{~nm}$, anthocyanins at $520 \mathrm{~nm}(n=3)$.

- Ribes nigrum (blackcurrant), $\square$ Ribes rubrum (redcurrant), $\square$ Ribes uva-crispa (gooseberry), $\square$ Sorbus aucuparia (rowanberry), $\square$ Aronia melanocarpa (chokeberry)

Figure 2. CIE-Lab colour coordinates for berry pomace powder. BC - Ribes nigrum (black currant), RC - Ribes rubrum (red currant), GB - Ribes uva-crispa (gooseberry), RB - Sorbus aucuparia (rowanberry), CB - Aronia melanocarpa (chokeberry).

Figure 3. FESEM images of dried and milled pomace particles. BC - Ribes nigrum (black currant), RC - Ribes rubrum (red currant), GB - Ribes uva-crispa (gooseberry), RB - Sorbus aucuparia (rowanberry), CB - Aronia melanocarpa (chokeberry).

Figure 4. Light microscopy images of dried and milled pomace particles. BC Ribes nigrum (black currant), CB - Aronia melanocarpa (chokeberry). Left column: bright field, right column: fluorescence.

Figure 5. Water vapour sorption isotherms of berry pomace powder at $20^{\circ} \mathrm{C}$ left: $\square$ Ribes nigrum (blackcurrant), $\square$ Ribes rubrum (redcurrant), $\square$ Ribes uvacrispa (gooseberry); right: - Sorbus aucuparia (rowanberry), $\square$ Aronia melanocarpa (chokeberry); Adsorption - full line, Desorption - dotted line; error bars represent deviation $(n=2)$ 


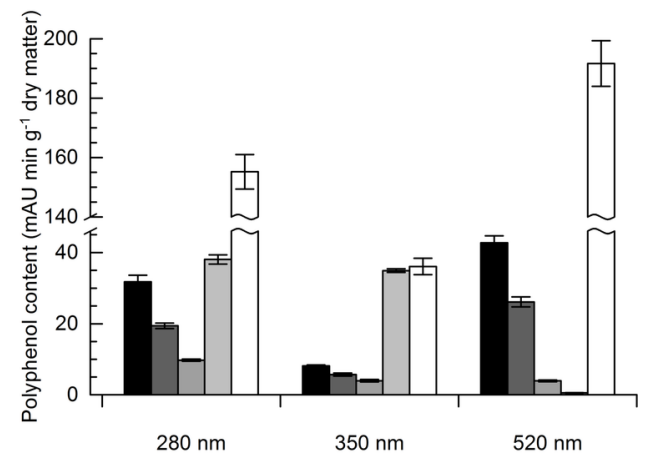

Figure1.TIF

This article is protected by copyright. All rights reserved. 


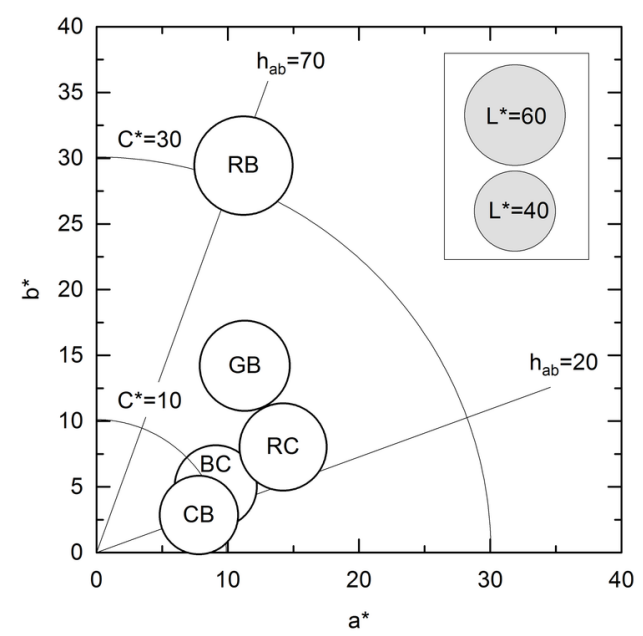

Figure2_new.TIF

This article is protected by copyright. All rights reserved. 


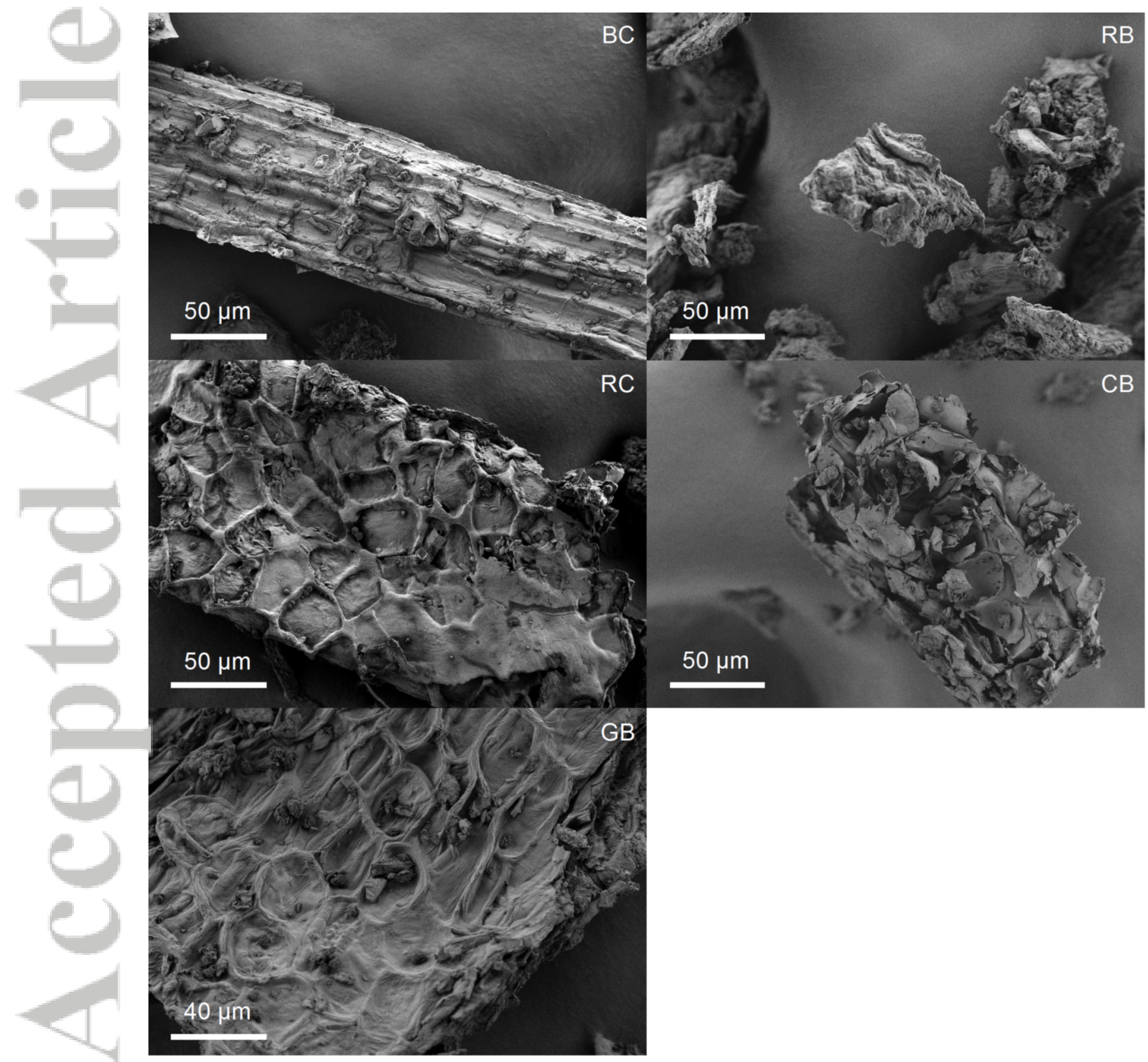

Figure3.TIF 


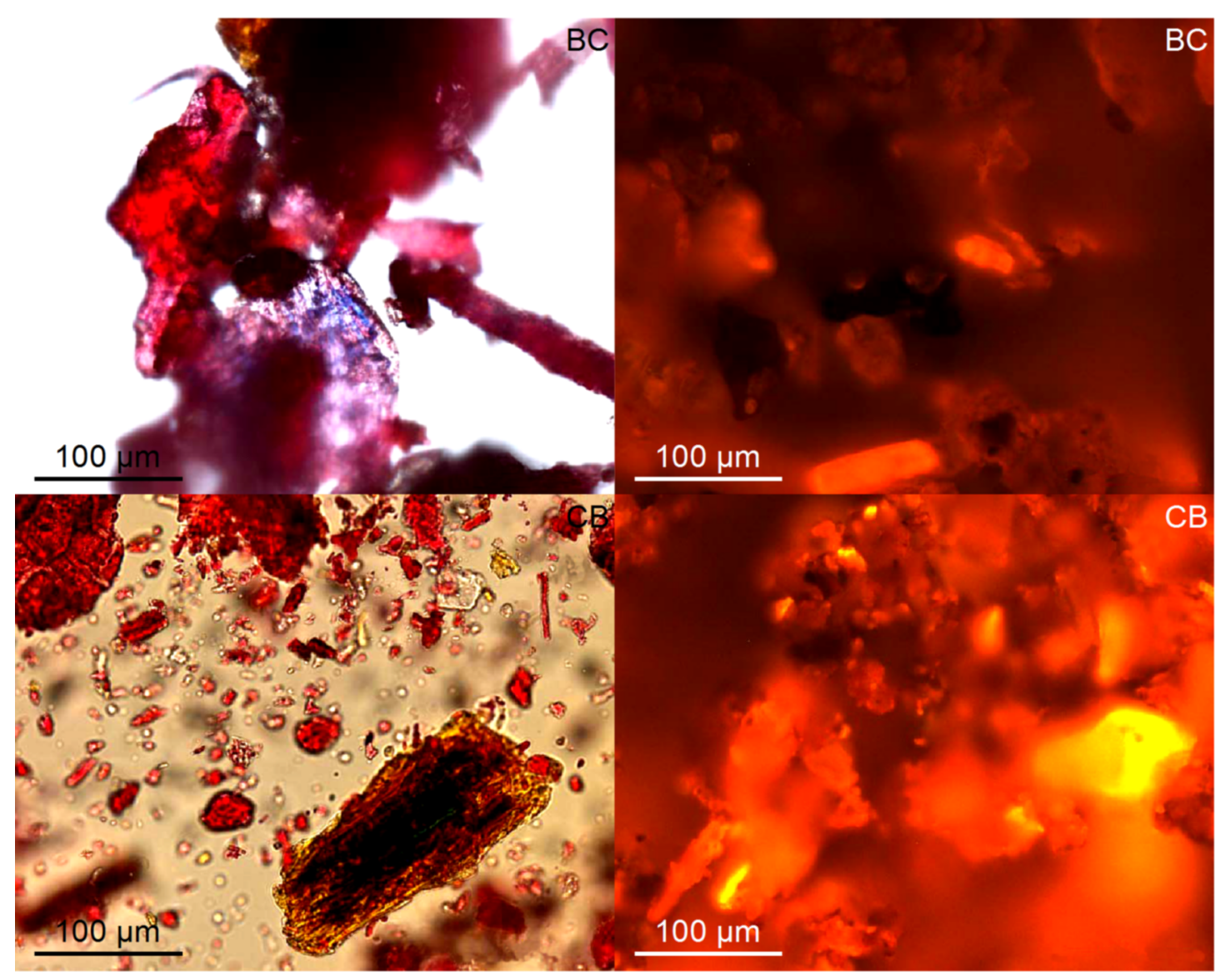

Figure4.TIF

This article is protected by copyright. All rights reserved. 


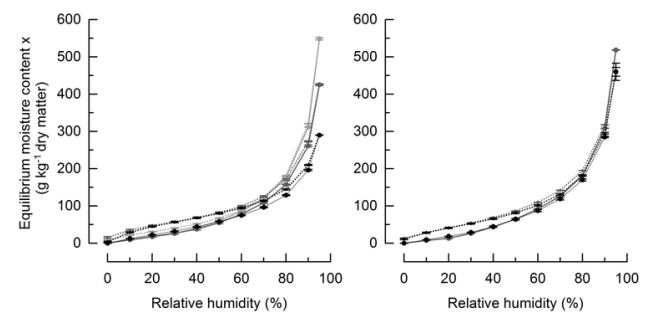

Figure5.TIF

This article is protected by copyright. All rights reserved. 